\title{
ODPOWIEDNIE STOSOWANIE PRZEPISÓW KODEKSU KARNEGO I KODEKSU POSTĘPOWANIA KARNEGO W POSTĘPOWANIU DYSCYPLINARNYM WOBEC KOMORNIKÓW
}

\begin{abstract}
Abstrakt: Artykuł dotyczy tak zwanego odpowiedniego stosowania przepisów ustaw karnych (kodeksu karnego z 1997 roku oraz kodeksu postępowania karnego z 1997 roku) w postępowaniu dyscyplinarnym wobec komorników sądowych. Głównym zagadnieniem jest tutaj kwestia zakresu i sposobu stosowania określonych przepisów wspomnianych ustaw w takim postępowaniu dyscyplinarnym oraz wyjaśnienie, czym w ogóle jest tak zwane odpowiednie stosowanie przepisów w prawie polskim.

Słowa kluczowe: prawo polskie, odpowiednie stosowanie przepisów, postępowanie dyscyplinarne wobec komorników sądowych, kodeks karny, kodeks postępowania karnego
\end{abstract}

Ustawowy nakaz „odpowiedniego stosowania przepisów”1 jest rozumiany w doktrynie (a raczej doktrynach) prawa niejednolicie. Wynika to oczywiście z niejednoznaczności tego pojęcia, ale także ze znanej prawnikom rozbieżności w zakresie terminologii prawnej oraz prawniczej w poszczególnych dyscyplinach nauk prawnych.

W literaturze ${ }^{2}$ nieraz można spotkać się $\mathrm{z}$ takim rozumieniem ustawowego nakazu „odpowiedniego” stosowania przepisów prawa, że istnieją niejako trzy jego modele: pierwszy ma polegać na stosowaniu przepisów bez żadnych modyfikacji, a więc „wprost”; drugi dopuszcza jedynie pewne modyfikacje w procesie stosowanr 3.

1 Por. J. Wróblewski, Przepisy odsyłające, „Zeszyty Naukowe Uniwersytetu Łódzkiego” 1964,

2 Zob. między innymi K. Dudka, Stosowanie przepisów kodeksu postępowania karnego w postępowaniach dyscyplinarnych uregulowanych w prawie o adwokaturze oraz ustawie o radcach prawnych, „Prawo w Działaniu” 2014, nr 18 (dostępne na: www.iws.gov.pl); idem, Odpowiedzialność dyscyplinarna oraz zakres stosowania przepisów k.p.k. w postępowaniu dyscyplinarnym wobec nauczycieli akademickich, „Studia Iuridica Lublinensia” 2007, nr 9, passim. 
nia prawa; trzeci - stanowi, że z uwagi na „bezprzedmiotowość” lub „sprzeczność” konkretnych przepisów nie mogą być one zastosowane dla danego postępowania ${ }^{3}$.

Powyższe rozumowanie wydaje się jednak o tyle niewłaściwe, że „odpowiednie" stosowanie przepisów można ogólnie określić jako ich stosowanie w sposób niesprzeczny z założeniami (celami) właściwego (to jest tego konkretnego) postępowania. Dlatego też wyraźny nakaz ustawodawcy w postaci zwrotu, że „do postępowania $[\ldots] \mathrm{w}$ zakresie nieuregulowanym $\mathrm{w}$ ustawie $[\ldots]$ stosuje się odpowiednio przepisy [...]", należy zrozumieć jako zobowiązanie podmiotów/ organów stosujących przepisy po pierwsze do stosowania ich w sposób niesprzeczny z przepisami konkretnej części danego aktu prawnego, a po drugie do korzystanie z przepisów ,innych" w sposób zgodny z ogólnymi celami danego postępowania (a więc w konsekwencji w „sposób” możliwie najmniej sformalizowany). Należy bowiem pamiętać, że „odpowiednie” stosowanie przepisów innej ustawy do ustawy właściwej nie może de facto oznaczać stosowania takich przepisów „wprost”. W innym przypadku ustawodawca nie nakazywałby przecież stosowania przepisów „odpowiednio”, tylko wskazał konkretny akt prawny lub też określoną jego część wraz z nakazem stosowania jego regulacji.

Częstym zabiegiem ustawodawcy jest nakaz zawarty w aktach prawnych tak zwanego „odpowiedniego stosowania przepisów kodeksu postępowania karnego"4, co dotyczy procedowania w odniesieniu do deliktów dyscyplinarnych. Wynika to oczywiście ze specyfiki postępowań dyscyplinarnych, które są wprawdzie niezależne od ewentualnych (i możliwych) postępowań karnych, ale ich konsekwencje dla obwinionego mogą być bardzo dotkliwe (i to nie tylko z uwagi na nieraz podnoszoną tak zwaną podwójną — jakoby — karalność, ale i często surowość kar przewidzianych za delikty dyscyplinarne, o czym będzie jeszcze mowa w dalszej części opracowania).

Jak wiadomo, postępowaniem karnym jest prawnie uregulowana działalność zmierzająca do realizacji prawa karnego materialnego, zaś przedmiotem procesu karnego jest kwestia odpowiedzialności karnej określonej osoby (podejrzanego/ oskarżonego) za określone przestępstwo ${ }^{5}$. Postępowaniem dyscyplinarnym jest więc prawnie uregulowana działalność zmierzająca do realizacji prawa regulującego odpowiedzialność zawodową (,materialną”, dyscyplinarną), w konsekwencji czego przedmiotem postępowania dyscyplinarnego będzie kwestia odpowiedzialności dyscyplinarnej określonej osoby (obwinionego) za określone przewinienie dyscyplinarne (to jest konkretny delikt zawodowy/dyscyplinarny).

Postępowania (procedury) dyscyplinarne uregulowane są w szeregu ustaw regulujących (z reguły) tak zwane zawody zaufania publicznego wraz ze wspo-

\section{Ibidem.}

${ }^{4}$ Ustawa z dnia 6 czerwca 1997 roku, Dz.U. z 2018 r. poz. 1987 ze zm.; zob. ponadto T. Grzegorczyk, Kodeks postępowania karnego oraz ustawa o świadku koronnym. Komentarz, Warszawa 2008, s. 45-51.

5 Ibidem, s. 45-46. 
mnianym wyżej (różnie formułowanym) nakazem „odpowiedniego stosowania przepisów kodeksu postępowania karnego". Można tutaj wskazać jedynie przykładowo na następujące akty prawne: ustawę z dnia 26 maja 1982 roku — Prawo o adwokaturze ${ }^{6}$ (art. 95n pkt 1); ustawę z dnia 6 lipca 1982 roku — O radcach prawnych $^{7}$ (art. 74.1 pkt 1); ustawę z dnia 14 lutego 1991 roku - Prawo o notariacie $^{8}$ (art. 69); ustawę z dnia 22 marca 2018 roku — O komornikach sądowych ${ }^{9}$ (art. 223 u. 2); ustawę z dnia 20 lipca 2018 roku — Prawo o szkolnictwie wyższym i nauce ${ }^{10}$ (art. 305 oraz art. 320); ustawę z dnia 2 grudnia 2009 roku — O izbach lekarskich ${ }^{11}$ (która w rozdziale 5 stanowi o „odpowiedzialności zawodowej” i w art. 112 pkt 1 nakazuje odpowiednio stosować przepisy kodeksu postępowania karnego, ale z wyłączeniem, ,przepisów o oskarżycielu prywatnym, powodzie cywilnym, przedstawicielu społecznym, o postępowaniu przygotowawczym oraz środkach przymusu, z wyjątkiem przepisów o karze pieniężnej”); czy też ustawa z dnia 13 października 1995 roku — Prawo łowieckie ${ }^{12}$ (art. 35s pkt 2) ${ }^{13}$.

Inną kwestią jest wyraźny nakaz ze strony ustawodawcy, by w takich ustawach stosować odpowiednie przepisy nie tylko kodeksu postępowania karnego, ale i w pewnym zakresie także przepisy kodeksu karnego. Jest tak właśnie w ustawie z dnia 22 marca 2018 roku regulującej status oraz odpowiedzialność dyscyplinarną komorników sądowych. Zgodnie z dwoma przepisami tej ustawy (art. 223 u. 1-2) odrębnie uregulowano kwestie tak zwanego odpowiedniego stosowania przepisów prawa karnego materialnego oraz odrębnie przepisów kodeksu postępowania karnego (a więc: prawa karnego procesowego). W pierwszym przypadku ustawodawca zdecydował, że w zakresie nieuregulowanym w ustawie o komornikach sądowych stosuje się odpowiednio przepisy rozdziałów I-III ustawy z dnia 6 czerwca 1997 roku — kodeks karny ${ }^{14}$; w drugim zaś — że do postępowania dyscyplinarnego $\mathrm{w}$ zakresie nieuregulowanym $\mathrm{w}$ ustawie o komornikach sądowych stosuje się odpowiednio przepisy kodeksu postępowania karnego.

6 Dz.U. z 1982 r. Nr 16, poz. 124 ze zm.

7 Dz.U. z 1982 r. Nr 19, poz. 145 ze zm.

8 Dz.U. z 1991 r. Nr 22, poz. 91 ze zm.

9 Dz.U. z 2018 r. poz. 771.

10 Dz.U. z 2018 r. poz. 1668.

11 Dz.U. z 2009 r. Nr 219, poz. 1708 ze zm.

12 Dz.U. z 1995 r. Nr 147, poz. 713 ze zm.

13 Powyżej — jak już zaznaczyłem - wymieniono tylko przykładowe ustawy regulujące postępowania dyscyplinarne wobec osób wykonujących konkretne zawody. Istnieją jednak pewne cechy charakterystyczne dla bodajże wszystkich aktów prawnych regulujących odpowiedzialność oraz procedurę dyscyplinarną. Jest to przede wszystkim poważny problem „odchodzenia” (mniej lub bardziej) od jedynej przecież wykładni statuującej dobre prawo — to jest od wykładni językowej. Wynika to zapewne z pewnego (wysoce niedoskonałego) trybu legislacyjnego, gdzie przepisy tworzone niejako na wzór przepisów procedury karnej (to jest na modłę przepisów dotyczących odpowiedzialności dyscyplinarnej) — są de facto projektowane przez osoby nie zajmujące się zawodowo prawem karnym, a tym bardziej prawem - procesowym.

14 Dz.U. z 2017 r. poz. 2204 oraz z 2018 r. poz. 20, 305 i 663. 
Zasadniczą kwestią jest więc tutaj zrozumienie podstawowej różnicy pomiędzy prawem materialnym a prawem procesowym, gdy należą one (w bardzo obszernej przecież regulacji prawa publicznego) do prawa karnego, które poza samym swoim założeniem (ratio legis), powinno dodatkowo cechować się wysoką gwarancyjnością regulacji dla obywateli państwa (i nie tylko obywateli, ale każdego potencjalnego uczestnika takiego postępowania), a musi także spełniać określone cechy przesądzające o tym, że jest to właśnie prawo karne, a nie prawo administracyjne. Istotny jest przede wszystkim fakt, że prawo materialne jest, rzecz jasna, tak zwanym prawem ,zamkniętym”, gdzie jakakolwiek interpretacja lub wykładnia wykraczająca poza tekst (język) aktu prawnego jest niedopuszczalna. Zgoła odmienna sytuacja dotyczy jednak prawa procesowego (w tym także prawa karnego procesowego), gdzie dopuszczalne jest już stosowanie tak zwanej wykładni rozszerzającej, a nawet analogii, z tym zasadniczym zastrzeżeniem, że nie wolno tego czynić w sposób, który ograniczałby prawa uczestników postępowania, a przede wszystkim stron, na czele z osobą obwinionego (oskarżonego w procesie karnym). Dlatego też prawo procesowe jest często określane jako tak zwane prawo „otwarte”.

W postępowaniach dyscyplinarnych, w których nakazuje się stosować zarówno prawo karne materialne, jak i prawo karne procesowe - czyli przykładowo prowadzonych na podstawie wspomnianej ustawy o komornikach sądowych — należy zawsze pamiętać o uprzednio wskazanej różnicy, z tym dodatkowym zastrzeżeniem, że ustawodawca wprost zdecydował, że odpowiednie stosowanie przepisów kodeksu karnego dotyczy jedynie jego pierwszych trzech rozdziałów (tak zwanej części ogólnej kodeksu karnego), czyli zasad odpowiedzialności karnej, form popełnienia przestępstwa (deliktu dyscyplinarnego) oraz wyłączenia odpowiedzialności karnej (dyscyplinarnej) i niczego ponadto.

Wskazano już także, że chyba najlepszym wyjaśnieniem pojęcia „stosowania odpowiedniego przepisów" wydaje się stosowanie przepisów (w tym przypadku określonej części kodeksu karnego oraz, co do zasady, całości kodeksu postępowania karnego) w sposób niesprzeczny z celami właściwego postępowania, to jest postępowania w sprawie odpowiedzialności dyscyplinarnej komorników sądowych.

Stosowanie „odpowiednie” przepisów jest bowiem ich stosowaniem w sposób niesprzeczny z założeniami (zasadami) właściwego (czyli tego konkretnego) postępowania. Jak już wyjaśniono, ustawowy nakaz w postaci zwrotu (w tym przypadku dotyczącego deliktów dyscyplinarnych komorników), że „do postępowania dyscyplinarnego $\mathrm{w}$ zakresie nieuregulowanym w ustawie o komornikach sądowych stosuje się odpowiednio przepisy kodeksu postępowania karnego" należy zrozumieć po pierwsze jako obowiązek dla podmiotów/organów stosujących przepisy karnoprocesowe, by stosowały je w sposób niesprzeczny z przepisami rozdziału 11 ustawy o komornikach sądowych (art. 222-260 ustawy); oraz po wtóre - jako korzystanie z przepisów kodeksu postępowania karnego zgodny z ogólnymi celami postępowania dyscyplinarnego wobec komorników sądowych, a więc — w konsekwencji — w sposób możliwie najmniej 
sformalizowany ${ }^{15}$. Należy bowiem pamiętać, że „odpowiednie” stosowanie przepisów innej ustawy do ustawy właściwej nie oznacza nigdy stosowania takich przepisów „wprost”. Stwierdzono już przecież wcześniej, że w innym wypadku ustawodawca nie nakazywałby stosowania przepisów „odpowiednio”, tylko wskazał konkretny akt prawny lub też określoną jego część wraz z nakazem stosowania jego regulacji. Tym bardziej nie oznacza to, że podczas procedowania w sprawie dyscyplinarnej przeciwko komornikowi sądowemu można stosować przepisy kodeksu postępowania karnego w całej ich rozciągłości i z całym ich formalizmem. Jest to nie tylko sprzeczne $\mathrm{z}$ daną ustawą regulującą konkretną profesję, ale też po prostu nielogiczne, wszak wtedy właśnie w praktyce osób tak procedujących pojawiają się najtrudniejsze zagadnienia prawne ${ }^{16}$.

Jak wskazano powyżej, w przepisach regulujących postępowanie dyscyplinarne wobec komorników sądowych inaczej unormowano stosowanie odpowiednie przepisów kodeksu karnego, inaczej - przepisów kodeksu postępowania karnego. Wiąże się to pośrednio z podnoszonym nieraz (także na początku niniejszych rozważań) rzekomym problemem „,podwójnej karalności”, czyli odpowiedzialności karnej za przestępstwo oraz dodatkowo za delikt dyscyplinarny. W tym miejscu należy wyrazić zdecydowany pogląd, że takiego problemu/naruszenia w istocie nie ma. Oczywiście dolegliwość orzeczenia kary dyscyplinarnej może być znaczna i nawet „dodatkowo odczuwalna” po jej wymierzeniu w następstwie zakończonego procesu karnego. Cele zakreślone przez ustawodawcę dla prawa i procesu karnego oraz dla prawa i postepowania dotyczącego odpowiedzialności dyscyplinarnej ( $w$ tym przypadku: odpowiedzialności dyscyplinarnej komorników sądowych) ${ }^{17}$ są jednak zupełnie inne. Zresztą w praktyce o wiele większe

15 Zupełnie kuriozalne jest zdarzające się wcale nierzadko w praktyce „formalizowanie” postępowań dyscyplinarnych i czynienie z nich swego rodzaju quasi-procesów karnych.

16 Należy zauważyć, że tak istotna kwestia jak odpowiedzialność dyscyplinarna (najczęściej przedstawicieli zawodów tak zwanego zaufania publicznego) jest regulowana w sposób nie zawsze precyzyjny. Przykładowo w wyżej wymienionej ustawie o komornikach sądowych dotyczy to zwłaszcza przepisów tak zwanych intertemporalnych (przejściowych, wynikających z tak zwanego czasu postępowań dyscyplinarnych), ale także i innych regulacji tej ustawy. Podkreślono już wcześniej, że najważniejszą wykładnią tekstu aktu prawnego jest wykładnia językowa i de facto jedynie ona powinna być stosowana w procesie interpretacji prawa państwa praworządnego. Problemem zaś praktycznym staje się nakaz — najczęściej zawarty w jednym zdaniu — ,aby w zakresie nieuregulowanym, stosować odpowiednio przepisy kodeksu postępowania karnego". W dodatku jest to nakaz kierowany nie tylko do procesualistów karnych, ale i wcale nierzadko do prawników w ogóle. Powoduje to w konsekwencji poważne problemy interpretacyjne, pojawiające się przy procedowaniu konkretnych deliktów dyscyplinarnych, a w konsekwencji może powodować nie tylko dopuszczanie się obrazy prawa, ale i naruszania praw osób, wobec których takie przepisy (a właściwie ich ,interpretacje") się stosuje.

$17 \mathrm{~W}$ niektórych sytuacjach postępowanie dyscyplinarne może nawet stać na straży praworządności w przypadku pewnych istniejących luk w prawie karnym (na przykład ukaranie dyscyplinarne za plagiat, który na gruncie wspomnianej wcześniej ustawy z dnia 20 lipca 2018 roku Prawo o szkolnictwie wyższym i nauce nie przedawnia się nigdy, nawet wtedy, gdy tak się stanie na podstawie przepisów kodeksu karnego). 
trudności w „stosowaniu odpowiednim przepisów” i tak będzie powodował nie kodeks karny, tylko kodeks postępowania karnego (z uwagi na zaznaczoną już wcześniej różnicę w charakterze tych dziedzin prawa).

Reasumując, wnioskiem podstawowym winno być założenie, że w postępowaniu dyscyplinarnym prowadzonym przeciwko/wobec komorników sądowych - czy to w odniesieniu do „odpowiedniego" stosowania prawa karnego materialnego (kodeksu karnego), czy też w odniesieniu do „odpowiedniego” stosowania prawa karnego procesowego (kodeksu postepowania karnego) - nie wolno formalizować postępowania dyscyplinarnego prowadzonego na podstawie przepisów ustawy o komornikach sądowych ponad stopień formalizacji wynikający właśnie $\mathrm{z}$ tej ustawy. Takie niebezpieczeństwo (formalizowania) powstaje przede wszystkim w przypadkach nieudolnego sięgania po przepisy procedury karnej, kiedy to w konsekwencji następuje procedowanie w swego rodzaju „drugim” procesie karnym, jeszcze bardziej obciążonym formalnie niż proces prowadzony przed sądem i dotyczący przestępstw, w tym zbrodni.

\section{THE APPROPRIATE APPLICATION OF REGULATIONS OF THE CRIMINAL CODE OF 1997 AND THE CODE OF CRIMINAL PROCEEDINGS OF 1997 IN DISCIPLINARY ACTIONS AGAINST COURT BAILIFFS IN POLAND}

Summary

The aim of this paper is a problem of so-called appropriate application of regulations of the criminal code (1997) and the code of criminal proceedings (1997) in disciplinary actions against court bailiffs in Poland; and what exactly means in the Polish law: "appropriate application of a bill/act".

Keywords: Polish law, so-called appropriate application of regulations, disciplinary action against court bailiffs, criminal code, code of criminal proceedings

\section{BIBLIOGRAFIA}

Dudka K., Odpowiedzialność dyscyplinarna oraz zakres stosowania przepisów k.p.k. w postępowaniu dyscyplinarnym wobec nauczycieli akademickich, „Studia Iuridica Lublinensia” 2007, nr 9.

Dudka K., Stosowanie przepisów kodeksu postępowania karnego w postępowaniach dyscyplinarnych uregulowanych $w$ prawie o adwokaturzeoraz ustawie o radcach prawnych, „Prawo w Działaniu" 2014, nr 18.

Grzegorczyk T., Kodeks postępowania karnego oraz ustawa o świadku koronnym. Komentarz, Warszawa 2008.

Wróblewski J., Przepisy odsyłające, „Zeszyty Naukowe Uniwersytetu Łódzkiego” 1964, nr 3. 